\title{
Dukungan Ekologi Berbasis Perkembangan Sosial untuk Meningkatkan Kemampuan Keterampilan Sosial Anak
}

\author{
Laila Maharani \\ Universitas Islam Negeri Raden Intan Lampung \\ lailamaharani@radenintan.ac.id
}

Diterima: Juni 2017. Disetujui: Oktober 2017. Dipublikasikan: Desember 2017

\begin{abstract}
Social skills in children are the basis for living with others. Therefore, a model of social-based ecological support is needed to improve the social skills of children. With the developmental ecology, the various potentials that exist in children can be facilitated, because the child's developmental ecology is the whole environment that allows children to get the facilities and the right stimulus, so that there is a healthy learning process. The research was conducted at TK Ar Rahman Bandar Lampung, in July-December 2017. The target of this research is the students of group B TK Ar Rahman as the main object of research and teacher as secondary object or model user. this study the authors only limit in the first stage of the preliminary study in the form of analysis of the next needs to be done further research by developing learning model.
\end{abstract}

Keywords : Behavior; Student; discipline; divorce

\begin{abstract}
Abstrak: Keterampilan sosial pada anak merupakan dasar untuk hidup berintraksi dengan orang lain. Oleh sebab itu diperlukan suatu model dukungan ekologis berbasis perkembangan sosial untuk meningkatkan kemampuan keterampilan sosial anak. Dengan ekologi perkembangan, berbagai potensi yang ada pada anak dapat difasilitasi, sebab ekologi perkembangan anak merupakan segenap lingkungan yang memungkinkan anak memperoleh fasilitas dan stimulus yang tepat, sehingga terjadilah proses belajar secara sehat. Penelitian dilaksanakan di TK Ar Rahman Bandar Lampung, pada Juli-desember 2017. Sasaran penelitian ini adalah peserta didik kelompok B TK Ar Rahman sebagai objek utama penelitian dan guru sebagai objek sekunder atau pengguna model. penelitian ini penulis hanya membatasi pada tahap pertama yaitu studi pendahuluan yang berupa analisis kebutuhan selanjutnya akan dilakukan penelitian lanjutan dengan mengembangkan model pembelajarannya
\end{abstract}

Kata Kunci : Behavior; Indisipliner; siswa; perceraian

\section{Pendahuluan}

Tidak dapat dipungkiri dalam perkembangan anak sering terjadi berbagai hambatan, sehingga terjadinya permasalahan dalam perkembangan selanjutnya. Adanya berbagai hambatan perkembangan anak tentunya membutuhkan bantuan seorang pendidik yaitu melalui penyediaan fasilitas dan stimulus yang tepat dalam perkembangannya.

Anak adalah investasi yang amat besar bagi keluarga dan bangsa. Anak-anak kita merupakan generasi penerus keluarga dan bangsa, oleh karena itu orang tua akan bahagia melihat anak-anaknya berhasil dalam pendidikan berkeluarga, masyarakat, dan karir (Suyanto, 2005). Hambatan perkembangan anak yang dominan tampak dari berbagai perilaku anak, yang mencakup: 1) masalah sosial meliputi; egois, perilaku sok kuasa, bertengkar dan agresif, 2)masalah emosional misalnya cemas, tidak mau berteman karena pemalu dan canggung, dan takut, 3) masalah moral misalnya; kesulitan memahami perkataan oranga dan 'lamban' dalam memahami penjelasan, dan 5) masalah bahasa misalnya; perkembangan bicara yang berada di bawah tingkat perkembangan anak seusianya, berbicara cepat sehingga sulit dimengerti dan memiliki perbendaharaan kata yang relatif sedikit dibangingkan teman seusianya(Bunu, 2012).

Konsep yang lebih dalam lagi yaitu tentang potensi kesadaran sosial yang biasa disebut juga dengan keterampilan sosial perlu dikembangkan pada masa anak usia dini, sebab 
keterampilan sosial merupakan dasar untuk hidup berinteraksi dengan orang lain, bekerja sama, mengontrol diri dan bertukar fikiran. Keterampilan sosial dipengaruhi oleh berbagai faktor seperti faktor genetik, lingkungan, budaya, kelainan otak, perlakuan dalam keluarga dan teman sebaya.

Dapat dinyatakan juga bahwa, "The ability to perform these important behavioural social skills is a necessary but insufficient determinant of competent social functioning”(Spence, 2003). Yang mana sesungguhnya, kemampuan keterampilan sosial itu merupakan hal penting untuk di perhatikan meskipun tidak cukup hanya melihatnya dari fungsi secara sosialnya saja. Informasi dari data sebuah penelitian menggambarkan bahwa sekitar 50\% anak-anak yang dirujuk ke bagian pendidikan khusus di sekolah, karena diidentifikasi mempunyai keterampilan sosial yang buruk dan cenderung di tolak oleh teman-teman sebayanya (Shapiro, 2001:35). Data tersebut menggambarkan bahwa keterampilan sosial pada anak menjadi lebih menonjol dibanding kesulitan dalam pelajaran sekolah. Ratusan studi menunjukkan bahwa penolakan oleh teman pada masa kanak-kanak menjadi salah satu faktor yang ikut menyebabkan buruknya prestasi akademik timbulnya masalah emosi, meningkatnya resiko kenakalan remaja.

Selain hal tersebut di atas, pencetus dari keterampilan sosial yang rendah pada anak, diyakini salah satunya adalah kondisi dan situasi pada diri anak yang mengalami keadaan atau berada di lingkungan tidak normal, seperti terjadinya traumatis di lingkungan sekitar anak tinggal, bisa menghambat perkembangan individu sebagai anak. Menurut Lochman dan Dodge dalam(Spence, 2003), “...deficit in interpersonal problem solving are associated with several form of child psychopathology including conduct disorder and depression". Kekurangan dalam memecahkan masalah interpersonal akan membentuk anak dengan perilaku disorder dan depresi. Kondisi lingkungan yang buruk ini tidak diharapkan oleh anak, bila hal tersebut dibiarkan berlarut-larut, bisa berdampak negatif terhadap perkembangan atau kondisi psikologis anak.

Berdasarkan pertimbangan bahwa masa anak adalah masa emas sekaligus masa kritis, maka upaya memfasilitasi dan menstimulasi harus diberikan secara tepat sesuai tahapannya. Artinya, dalam menfasilitasi dan menstimulasi perkembangan anak harus memperhatikan tugastugas perkembangan sesuai rentang usia anak. Di sisi lain, dalam perkembangannya, setiap anak didik di TK memerlukan kesempatan untuk mengembangkan diri melalui proses belajar. Proses belajar ini diperoleh anak melalui interaksinya dengan lingkungan di mana anak berada. Lingkungan yang memungkinkan individu memperoleh proses belajar yang dimaksud adalah tersedianya ekologi perkembangan bagi anak.

Dukungan ekologi perkembangan mempunyai peranan penting bagi perkembangan anak. Dengan ekologi perkembangan, berbagai potensi yang ada pada anak dapat difasilitasi, sebab ekologi perkembangan anak merupakan segenap lingkungan yang memungkinkan anak memperoleh fasilitas dan stimulus yang tepat, sehingga terjadilah proses belajar secara sehat. (Kauchak \& Eggen, 2007:348-349) menyatakan: "Intervensi untuk membantu perkembangan anak seyogyanya tidak diarahkan hanya kepada anak itu saja melainkan juga kepada lingkungannya, baik lingkungan fisik mapun lingkungan sosialnya sehingga iklim pembelajaran menekankan pada kebermaknaan dan mampu membangkitkan daya kritis dan kreatif anak. Perkembangan intelektual, emosional, sosial, sensoris, dan fisik bukan semata-mata akibat struktur biologis yang defektif, melainkan merupakan produk interaksi antara karakteristik struktur biologis dengan variabel lingkungan”.

Berdasarkan paparan di atas, semakin jelas bahwa lingkungan sangat berpengaruh pada perkembangan anak. Pentingnya pencapaian tugas perkembangan anak di usia dini serta relevansinya dengan pendekatan ekologis dalam optimalisasi tugas perkembangan. Diasumsikan 
bahwa pendekatan ekologis dapat memfasilitasi dan menstimulasi pencapaian tugas perkembangan aspek sosial anak secara optimal.

Senada dengan paparan di atas, Jackman (20122) menyatakan bahwa pada dasarnya pendidikan ekologi merupakan bagian dari sebuah pendekatan terpadu yang sedang berlangsung tentang bagaimana anak berfikir dan membangun dasar pemahaman tentang dunianya. Pendidikan ekologi dilakukan oleh manusia akan memberi manfaat kemanusiaan. Ekologi dari sudut pandang kecerdasan yang harus dimiliki anak. Ekologis artinya pemahaman terhadap organisme dan ekosistemnya, sedangkan kecerdasan ekologis adalah kemampuan kita untuk beradaptasi terhadap lingkungan ekologis tempat kita berada. Kecerdasan ekologis membuat kita menerapkan apa yang dipelajari sebagai aktivitas manusia terhadap ekosistem, Oleh karena itu anak sebaiknya merasakan ada interaksi antara dirinya dengan lingkungan sekitarnya, seperti lingkungan biotik maupun abiotik(Goleman, 2009).

Berdasarkan hal-hal yang telah diuraikan sebelumnya, maka diperlukan suatu model dukungan ekologis berbasis perkembangan sosial untuk meningkatkan kemampuan keterampilan sosial anak. Tingkat kesadaran sosial merupakan salah satu potensi yang perlu dikembangkan pada anak usia dini, dan dalam hal ini dikatakan sebagai suatu keterampillan sosial, sangat penting dalam kehidupan sosial setiap individu termasuk anak di dalamnya, untuk menjalani kehidupan selanjutnya. Keterampilan sosial merupakan dasar untuk hidup berintraksi dengan orang lain, bekerja sama, mengontrol diri dan bertukar pikiran. Keterampilan sosial dipengaruhi oleh berbagai faktor seperti faktor genetik, lingkungan, budaya, kelainan otak, perlakuan dalam keluarga dan teman sebaya.

Informasi dari data sebuah penelitian menggambarkan bahwa sekitar $50 \%$ anak-anak yang dirujuk ke bagian pendidikan khusus di sekolah karena di identifikasi mempunyai keterampilan sosial yang buruk dan cenderung di tolak oleh teman-teman sebayanya. Data tersebut menggambarkan bahwa masalah sosial pada anak menjadi lebih menonjol di banding kesulitan dalam pelajaran sekolah. Ratusan studi menunjukkan bahwa penolakan oleh teman pada masa kanak-kanak menjadi salah satu faktor yang ikut menyebabkan buruknya prestasi akademik timbulnya masalah emosi, meningkatnya resiko kenakalan remaja.

Usia dini merupakan saat yang amat berharga untuk menanamkan nilai-nilai nasionalisme, kebangsaan, agama, etika, moral dan sosial yang berguna untuk kehidupannya dan strategis bagi pengembangan suku bangsa. Hakikat TK dan perkembangannya tidak terlepas dari teori perkembangan anak dalam psikologi, pendidikan dan sosiologi(Amir Hasan Dawi, 2006). Masa kanak-kanak merupakan produk sosial dari kultural dan struktural masyarakat. Beragam pemahaman tentang masa kanak-kanak terkait dengan perkembangan anak usia dini. Memandang anak sebagai bagian dari masyarakat yang harus diberi dukungan dan diarahkan oleh kekuatan eksternal agar menjadi anggota masyarakat yang benar-benar memiliki fungsi di dalam masyarakat ( a fully functioning member)(Prasadja, 2008). Mencermati hal ini maka memandang anak sebagai bagian dari masyarakat tentunya harus diberikan pembelajaran sebagai unsur personalitas agar anak memiliki orientasi nilai positif sebagai bagian dari anggota masyarakat. Sementara itu menurt Lev Vygotsky menegaskan bahwa perkembangan anak tergantung pada hubungan antar beberapa faktor. Sama halnya dengan Piaget, Vygotsky dalam John W.Santrock(2010:240-251) menekankan bahwa perkembangan berbeda berdasarkan penekanan hubungan antara internal organism dan social milieu. Penekanan pada pengaruh proses sosio-budaya yang terjadi dalam menstimulasi perkembangan individu, selanjutnya disebut dengan Socio-Historical Theory of Cognitive Development. Vygostky meyakini 
perkembangan yang terjadi merupakan hasil dari interaksi sosial anak dalam sistem budaya unik serta latar belakang sejarah.

Selanjutnya mengenai perkembangan anak, teori Bronfenbrenner mengatakan bahwa perkembangan anak sangat dipengaruhi oleh sistem interaksi dengan lingkungan sosial sebagai struktur yang terangkai, dan jika demikian maka terjadinya interaksi sosial merupakan sesuatu hal yang sangat penting sebab merupakan mesin penggerak dari proses perkembangan anak selanjutnya. Di dalam keseluruhan penelitian ini penulis mencoba memberikan pemikiran dengan berdasar pada teori-teori tentang perkembangan anak sebagai acuan, dengan harapan mengembangkan perkembangan anak dalam konteks sosial tertentu sehingga konteks ini dapat mengubah perkembangan untuk membentuk lingkungan guna mengoptimalkan potensi genetik anak usia dini. Banyak teori dan definisi kecerdasan. Kecerdasan antara lain didefinisikan sebagai kemampuan menghasilkan ide yang gemilang dan memecahkan masalah secara kreatif, efisien, dan bijaksana. Demikian pula menggambar bebas dengan kuas besar, lalu kuas kecil, dan mewarnai mengembangkan otot-otot halus pada jari tangan. Hal itu akan sangat bermanfaat untuk melatih jari anak agar bisa memegang pensil dan belajar menulis(Suyanto, 2005).

Agar tubuh anak dapat berkembang secara optimal, kegiatan-kegiatan yang perlu dilakukan antara lain adalah: Program peningkatan gizi dengan pemberian makanan yang bergizi dan seimbang, Program pengecekan kesehatan secara rutin, Program olah raga, seperti gerak dan lagu, dimana anak dapat bergerak bebas seperti senam pagi diringi lagu yang meriah dan menyenangkan anak, Program peningkatan aktifitas fisik melalui bermain, seperti outdoor play, dimana anak diberi waktu untuk bermain di halaman sekolah atau dilapangan dengan berbagai ragam alat-alat permainan yang mengembangkan fisik dan motorik kasar, Jalan-jalan pagi dan kegiatan luar kelas lainnya (autdoor activities), Memberi kegiatan yang mengembangkan kemampuan motorik halus, seperti menempel, menggunting, mengancing baju, menali sepatu, dan menggambar.

Menurut Piaget, semua anak memiliki pola perkembangan kognitif yang sama yaitu melalui empat tahapan: (1) sensori-motor, (2) pre-operasional, (3) konkrit-operasional, dan (4) formal-operasional, (Piaget,1965). Ke-empat tahap perkembangan tersebut berlaku serentak disemua bidang perkembangan kognitif. Sebagai contoh anak yang masih berpikir konkrit operasional dalam matematika, akan berpikir konkrit operasional pula dalam bahasa dan sains. Hanya saja waktu yang dibutuhkan anak untuk mencapai suatu tahapan berbeda satu dengan yang lain(Hijriati, 2016).

Perkembangan moral anak ditandai dengan kemampuan anak untuk memahami aturan, norma dan etika yang berlaku. Piaget ${ }^{1}$ membagi perkembangan moral ke dalam tiga tahap. Pertama disebut Premoral. Pada tahap ini anak belum memiliki dan belum dapat menggunakan pertimbangan moral untuk perilakunya. Hal ini disebabkan anak tidak berpengalaman bersosialisasi dengan orang lain dan masyarakat dimana aturan, etika dan norma itu ada. Di samping itu anak juga masih bersifat egosentris, belum dapat memahami perspektif atau cara pandang orang lain. Kedua disebut Moral Realism.

Tanggung jawab sosial antara lain ditunjukkan oleh komitmen anak terhadap tugastugasnya, menghargai perbedaan individual, memperhatikan lingkungannya, dan mampu menjalankan fungsinya sebagai warga negara yang baik. Piaget (1975) menunjukkan adanya sifat egosentrisme yang tinggi pada anak di mana anak belum dapat memahami perbedaan perspektif pikiran orang lain. Menurut anak, orang lain berpikir sebagaimana ia berpikir. Parten menunjukkan hal itu antara lain dari pola bermain pada anak. Sampai usia tiga tahun anak lebih 
banyak bermain sendiri (soliter play), baru kemudian mereka mulai bermain sejenis (parallel play), mulai bermain melihat temannya bermain (on-looking play) dan kemudian bermain bersama (cooperative play). Mencermati dari aspek dukungan ekologi perkembangan sosial anak, dimaksudkan Bronfenbrenner sebagai pandangan sosiokultural perkembangan anak terdiri dari lima sistem lingkungan. Anak tidak pernah terpisah dari lingkungan, dan secara terusmenerus berinteraksi dalam waktu lama. Interaksi ini menjadi motor penggerak perkembangan anak. Bronfenbrenner juga (1979:25 \&29) menekankan bahwa anak merupakan pusat dari lingkaran, dikelilingi oleh berbagai sistem interaksi. Membedakan lingkungan anak menjadi empat struktur yang saling tersarang (nested) yaitu yang terdiri dari sistim meso, exo makro dan krono.

Penelitian mengambil latar sistem mikro dan meso. Sistem meso didefinisikan sebagai kegiatan, peran dan relasi yang dialami anak dalam sebuah latar atau beberapa setting sekaligus seperti rumah, tetangga, sekolah dan teman sebaya. Masing-masing sistem mempengaruhi perkembangan anak, menekankan perhatian pada interaksi antar setting. Meski anak berkembang tidak berada di dalamnya, namun struktur sosial mempengaruhi immediate setting dimana anak tinggal. Lebih lanjut Bronfenbrenner menekankan bahwa anak mengalami perkembangan positif jika berkembang secara intelektual, emosional, sosial dan moral. Jika memiliki hubungan interpersonal yang kuat, kedekatan emosi antara pengasuh dan anak, dukungan pemantapan serta pemeliharaan pola-pola interaksi timbal balik yang semakin kompleks.

Interaksi dilakukan anak dengan teman sebaya dan orang dewasa untuk mengembangkan kedekatan emosi. Hubungan interpersonal yang kuat hendaknya meningkatkan respons anak terhadap lingkungan fisik dan sosialnya. Sebagai mahluk sosial memerlukan dukungan melakukan tugas perkembangan, dukungan sosial dipahami S.Cohen and SL.Syme (1988:180188) sebagai suatu bentuk hubungan sosial yang bersifat menolong dengan melibatkan aspek emos, informasi, bantuan instrumen dan penilaian. Pandangan serupa disampaikan Icacy dalam Ganster (1988:839-852) menyatakan bahwa dukungan sosial merupakan hubungan yang memiliki nilai positif bagi si penerima dukungan. Turner, Frankel dan Lewin dalam Loyal dan Delonges dalam irwanto (2008) menyatakan bahwa anak menerima dukungan sosial sebagai pengalaman pribadi terhadap hubungan sosialnya dengan orang lain.. Cabb dalam Gottlieb (1983:18-28) menyatakan bahwa setiap informasi dari lingkungan sosial menimbulkan persepsi anak menerima efek positif, penegasan dan bantuan. Melalui kontak sosial dan tersedianya bantuan menandakan ungkapan ari adanya dukungan sosial. Johnson dan Johnson (1991:8-18) menjelaskan dukungan sosial merupakan pemanfaatan sumber-sumber di lingkungan anak, dengan cara meningkatkan kemampuan melalui pemberian bantuan berupa penerimaan diri, dorongan dan peralatan.

Pendapat serupa disampaikan Sarason, Lerin dan Basham (44:127-130), mendefinisikan dukungan sosial sebagai keadaan bermanfaat. Anak mengetai dengan pasti bahwa orang memperhatikan, menghargai dan mencintai. Kaplan dalam Lin (1988:247-263) mengatakan dukungan sosial merupakan kebutuhan seperti persetujuan, esteem dan pertolongan yang diperoleh dari orang-orang yang mempunyai arti bagi anak. Ganster, Fusilier dan Mayer (1988:102-110) mengemukakan dukungan sosial secara luas didefinisikan sebagai tersedianya hubungan bersifat menolong dan memiliki nilai khusus. Mengkonotasikan adanya ikatan sosial yang bersifat positif. Kaplan dalam Seers (1988:273-284) mengemukakan dukungan sosial merupakan tindakan menolong dan ketentraman berkomunikasi dengan orang lain. 
House dalam Sarafino (1994:38-48) membedakan dimensi dukungan sosial yaitu dukungan emosional, penghargaan, instrumental dan informatif. Pendapat schefer dan lazarus dalam Ronald dan Paul (1984:156-163) menetapkan dimensi dukungan sosial berupa dukungan emosional melibatkan keakraban dan penerimaan yang memberi keyakinan. Dukungan sosial berwujud atau memberi pelayanan atau bantuan secara langsung. Dukungan informasi meliputi pemberian nasihat, pemecahan masalah dan penilaian terhadap perilaku individu. Sebaliknya menurut Parsons (1951:8) tingkat dukungan sosial individu berbeda. Keadaan ini disebabkan karena terdapat perbedaan persepsi dalam menerima atau merasakannya.

Mengacu pada uraian di atas, dapat di tarik kesimpulan bahwa proses penerimaan dukungan sosial merupakan suatu pengalaman pribadi yang melibatkan penghayatan diri dan hubungan sosialnya dengan orang lain. Berfungsinya dukungan sosial dipengaruhi oleh adanya persepsi yang diberikan pada anak, memiliki hubungan interpersonal timbal balik yang sangat kuat. Menekankan pemahaman atas pengalaman positif berupa dukungan intelektual, emosional, sosial dan moral dalam lingkungan mikro, mezo, eko, makro dan kronosistem.

Anak yang dapat mengatasi persoalan sosialnya, akan memudahkan mereka dalam menghadapi persoalan akademisnya di sekolah sesuai jenjang pendidikannya.Pembelajaran keterampilan untuk anak-anak kebanyakan secara umum diperoleh melalui apa yang dilihat dan ditiru dalam lingkungan sosialnya. Pengertian keterampilan sosial adalah kemampuan anak untuk berinteraksi dengan orang lain pada konteks sosialnya (Milburn,2002).

Pendapat lain menyatakan bahwa keterampilan sosial merupakan pengetahuan tentang perilaku manusia dan proses antar pribadi, kemampuan memahami perasaan, sikap,motivasi orang lain tentang apa yang dikatakan dan dilakukannya dan kemampuan untuk berkomunikasi dengan jelas dan efektif serta kemampuan membangun hubungan yang efektif dan kooperatif. (Joice S.Oslond dkk, 2000).

Konsep model yang dikembangkan mengacu pada model pembelajaran sosial. Model pembelajaran sosial merupakan pengembangan dari teori belajar perilaku behavioristik, dimana sebagian manusia belajar melalui pengaamatan secara selektif dan mengingat tingkah laku orang lain. Gabriel Tarde dalam Soekanto, berpendapat bahwa seluruh kehidupan sosial didasarkan pada faktor imitasi (Soekanto,1990).

Walker dalam Rosenberg, (1992:414) menjelaskan keterampilan sosial secara umum diartikan sebagai respon-respon dan keterampilan yang memberikan seorang individu untuk dan mempertahankan hubungan positif dan berinteraksi secara interpersonal dan intrapersonal dengan orang lain. Penerimaan teman-teman sebayanya, penguasaan ruang kelas yang baik dan memberikan individu untuk mengatasi secara efektif dan bisa diadaptasi dengan lingkungan sosial. Dalam banyak penelitian keterampilan sosial sudah diartikan secara operasional untuk melingkupi harapan yang sesuai dengan umur dan sesuai dengan norma-norma yang ada terhadap sebuah cakupan yang luas dari perilaku-perilaku termasuk kontak mata, kualitas dan kuantitas interaksi teman sebaya, bermain, perilaku dalam percakapan, memulai kontak dan merespon orang-orang dewasa dan ekspresi yang sesuai dengan perasaan positif dan negatif.

Menurut Devins dalam Sujiono (2004:1) Keterampilan sosial sebagai suatu kemampuan untuk menilai apa yang sedang terjadi dalam suatu situasi sosial; keterampilan untuk merasa dan degan tepat menginterprestasikan tindakan dan kebutuhan dari anak-anak di kelompok bermain; kemampuan untuk membayangkan bermacam-macam tindakan yang memungkinkan dan memilih salah satunya yang paling sesuai. mbentukan keterampilan sosial anak usia dini seharusnya mendapat perhatian yang serius, anak adalah mahkluk yang aktif dan penjelajah 
yang adaptif yang selalu berupaya untuk mengontrol lingkungannya dan anak bukanlah anak yang pasif yang mau begitu saja dibentuk oleh kedua orang tuanya(Machmud, 2013).

Seefeldt dan Barbaur, (1998) Mengatakan bahwa keterampilan sosial meliputi keterampilan berkomunikasi, "sharing" (berbagi), bekerja sama, berpartisipasi dalam kelompok masyarakat. Anak-anak yang mempunyai kesadaran diri yang kuat siap untuk belajar hidup dan bekerja dengan orang lain. Jadi keterampilan sosial adalah perilaku-perilaku yang dipelajari, yang digunakan individu dalam situasi-situasi interpersonal untuk memperoleh atau memelihara pengukuhan dari lingkungannya. Keterampilan sosial menurut Jarolimek (1977:208), mencakup: (1) "Living and Working together; taking tums; respecting the rights of others; being socially sensitive (2) Learning self control and self direction; (3) Sharing ideas and experience with others". Dari pendapat tersebut di atas, dapat disimpulkan bahwa keterampilan sosial itu memuat aspek-aspek keterampilan untuk hidup dan bekerja sama, keterampilan untuk mengontrol diri dan orang lain, keterampilan untuk saling berinteraksi antara satu dengan yang lainnya, saling bertukar fikiran dan pengalaman sehingga tercipta suasana yang menyenangkan bagi setiap anggota dari kelompok tersebut.

Beberapa pemikiran tersebut di atas, dapat disimpulkan bahwa agar keterampilan sosial anak dapat berkembang dengan baik maka hal yang perlu diusahakan adalah: (1) interaksi individu dalam suatu kelompok, ini bisa terlaksana apabila individu dalam kelompok telah dibekali dengan keterampilan seperti cara berbicara, mendengar, memberi pertolongan dan lain sebagainya, serta (2) suasana dalam suatu kelompok. Suasana dalam kelompok itu hendaknya memberi kesan semua anggota bahwa mereka dianggap setaraf (equal), untuk itu penting saling menerima dan menghargai pendapat masing-masing menerima perbedaan dan mampu mengontrol diri.

Dari definisi di atas dapat disimpulkan bahwa keterampilan sosial sebagai perilakuperilaku yang ditunjukkan untuk merespon terhadap situasi yang ada, bertujuan menjalin hubungan dengan orang lain secara tepat dan diharapkan dalam hubungan/interaksi tersebut bermanfaat bagi masing-masing individu. Keterampilan sosial juga melibatkan kemampuan seseorang dalam berpikir sehingga ia mampu melihat petunjuk-petunjuk sosial yang berada di sekitarnya atau memahami perasaan individu lainnya. Keterampilan sosial sendiri memiliki cakupan yang luas dan berkaitan dengan cara-cara praktis yang harus dilakukan individu dalam bersosialisasi dengan orang-orang di sekelilingnya.

\section{Metode Penelitian}

Penelitian ini menggunakan metode penelitian kualitatif deskriptif dibutuhkan waktu yang panjang untuk membaca banyak buku dan teori, melakukan analisis kebutuhan atau studi lapangan, melakukan focus group discussion ke berbagai pihak dan masuk ke dalam kelas untuk melihat bagaimana kemampuan keterampilan sosial anak di sekolah dan melihat bagaimana upaya yang sudah dilakukan guru di sekolah. Penelitian dilaksanakan di TK Ar Rahman Bandar Lampung, pada Juli 2017 sampai Desember 2017. Sasaran penelitian ini adalah peserta didik kelompok B TK Ar Rahman sebagai objek utama penelitian dan guru sebagai objek sekunder atau pengguna model.

Pada studi ini menganalisis dengan menggunakan teknik wawancara, observasi dan dokumen analisis untuk melihat data yang jelas dan akurat di lapangan, namun demikian rancangan dalam penelitian ini sampai tahap ke empat diuraikan tahapannya. Sasaran penelitian ini adalah siswa kelompok B TK Ar Rahman Propinsi Lampung sebagai objek utama penelitian berjumlah 20 siswa dan 1 orang guru sebagai objek sekunder atau pengguna model. 


\section{Hasil dan Pembahasan}

1. Pembahasan Model Dukungan Ekologis Berbasis Perkembangan di kelompok A TK Ar Rahman.

Berdasarkan hasil penelitian pendahuluan, terungkap bahwa pembelajaran dukungan perkembangan sosial di TK Ar Rahman tahun 2017 dilakukan dengan sistim sentra. Dalam pembelajaran inti, anak di bagi dua kelompok oleh guru, kemudian satu kelompok diberikan kertas kerja dan satu kelompok lainnya dibimbing untuk melakukan kegiatan lain. Hal ini bertentangan dengan semangat pembelajaran yang menjadi ciri khas pembelajaran sentra yaitu berpusat pada anak karena ada tidak diberi kesempatan memilih kegiatan yang menarik bagi mereka. Hal ini juga bertentangan dengan teori Erikson.

Menurut Erikson (1990:247-267) pada usia pra sekolah kira-kira 3-5 tahun adalah masa inisiatif dengan rasa bersalah (initiative versus guilt) implikasi teori ini guru harus mengupayakan agar anak didik secara demokratis dan mengupayakan memberikan kondisi yang kondunsif dan menantang. (I Nyoman,2014:131). Sehingga anak-anak harus distimulasi inisatif, jadi tidak semua kegiatan harus ditentukan oleh guru agar masa inisiatif anak bisa tumbuh menjadi anak yang cerdas.

Pembelajaran ekologi berbasis perkembangan yang dilaksanakan selam ini di TK Ar Rahman kurang memberikan kesempatan anak untuk bereksplorasi. Hal ini bertentangan dengan smith (2013) bahwa isu tentang perkembangan anak pada abad 21 adalah: anak sebagai pembuat makna dan pembelajar aktif. Padahal gagasan dari teori Piaget dapat diimplikasikan dengan: (1) memberikan kesempatan anak menyusun pengetahuannya sendiri, (2) melakukan kegiatan fisik dan mental karena pengetahuan anak disusun lewat keterlibatan aktif mempelajari objek yang ada di lingkungan; (3) memberikan pengalaman yang menarik dan bermakna; (4) belajar aktif sangat membantu anak dalam kegiatan memecahkan masalah.

Selama semester 1 tahun ajaran 2017/2018, belum pernah dilakukan praktek keterampilan sosial. Pembelajaran sosial emosioanl lebih ditekankan pada pemberian tugas dengan mengisi lembar kerja. Padahal menurut Lind (2013), pembelajaran sosial emosional merupakan saat yang tepat bagi anak untuk mengajukan pertanyaan, melakukan penyelidikan, mengumpulkan data dan mencari jawaban. Strategi terbaik dapat dicapai dengan mencari fenomena alam yang dapat dipelajari dari waktu ke waktu. Anak-anak perlu memiliki kesempatan untuk bertanya dan menjawab pertanyaan, melakukan penyelidikan, dan belajar untuk menerapkan keterampilan pemecahan masalah.

Inti dari pembelajaran dukungan ekologi berbasis perkembangan anak yang baik adalah berpusat pada siswa dan aktif penyelidikan. Jika tidak diberikan kesempatan untuk melakukan eksplorasi maka akan berkurang kesempatan bagi anak untuk aktif menyelidiki. Padahal menurut Wolfe dan Mayers, semangat penyelidikan merupakan pusat ilmu pengetahuan, dan bermain dengan eksplorasi di masa kecil meletakkan dasar untuk penyelidikan ilmiah dewasa. Anak mempelajari dukungan ekologi perkembangan sosial dengan mengeksplorasi dunia yang ada di sekitar mereka.

Hasil penelitian menunjukkan, kegiatan yang dilakukan dalam pembelajaran ekologi perkembangan sosial di TK Ar Rahman kurang menekankan pada proses. Padahal menurut Henniger, proses diperoleh melalui: investivigasi, mengumpulkan data, membuat solusi antara global, menguji solusi, menyimpulkan dan berbagi informasi dengan yang lain. Metode yang 
digunakan adalah penemuan melalui pengamatan dan eksplorasi seperti eksplorasi sensori dan investigasi benda.

Penilaian guru dilakukan setelah pembelajaran berlangsung dengan menilai lembar kerja anak yang lebih menekan pada aspek kognitif. Jadi penilaian tidak dilakukan sepanjang pembelajaran berlangsung. Hal ini juga didukung oleh hasil wawancara dengan kepala TK bahwa dalam pembelajaran dukungan ekologis berbasis perkembangan yang telah dilaksanakan di TK ini belum secara bersamaan mengukur aspek perkembangan kognitif, sosial emosional dan intelektual adalah yang paling efektif.

Berdasarkan hasil penelitin dan pembahasan maka dapat disimpulkan bahwa pembelajaran ekologi berbasis perkembangan kelompok B TK Ar Rahman yang dilaksanakan selama ini yaitu pada tahun 2017 belum mencirikan karakteristik pembelajaran ekologi perkembangan berbasis perkembangan sosial.

2. Pembahasan Pembelajaran Dukungan Ekologi di TK AR Rahman pada tahun 2017.

Pelaksanaan penelitian dimulai bulan Juli sampai Desember 2017. Penelitian ini telah dilakukan pada 36 responden, dukungan ekologi perkembangan sosial yang dilakukan selama tahun 2017 di TK AR Rahman Bandar Lampung adalah: (1) pembelajaran berlangsung di ruangan sentra, namun anak tidak diberikan kesempatan memilih kegiatan sesuai minat karena semua anak melakukan kegiatan yang sama; (2) selama pembelajaran berlangsung guru kurang memberikan penekanan pada proses kemampuan sosial; (3) Pembelajaran kemampuan sosial yang dilaksanakan kurang memberikan kesempatan anak untuk bereksplorasi dengan perkembangan sosial ; (4) media pembelajaran yang digunakan kurang bervariasi; (5) pembelajaran dukungan ekologi tidak berbasis perkembangan sosial dan (6) penilaian dilakukan setelah pembelajaran berlangsung.

Kelebihan pembelajaran dukungan ekologi di TK AR Rahman pada tahun 2017 adalah: (1) guru membuat sendiri lembar kerja anak yang disesuaikan dengan RKH; (2) pembelajaran yang dilakukan sudah sesuai dengan tema kegiatan; dan (3) guru memberikan kesempatan anak untuk bermain bebas jika mereka telah selesai mengerjakan lembar kerja. Kendala yang dihadapi selama ini adalah kurang bervariasinya media pembelajaran dukungan ekologi anak, dan durasi pembelajaran dukungan ekologi hanya satu jam membuat guru kesulitan merancang pembelajaran dukungan ekologi yang menekankan eksplorasi.

Pembelajaran dukungan ekologi yang berlangsung di ruangan sentra tidak memberikan kesempatan bagi peserta didik memilih kegiatan sesuai minat karena semua anak melakukan kegiatan yang sama. Hal ini bertentangan dengan semangat pembelajaran yang menjadi ciri khas pembelajaran sentra yaitu berpusat pada anak karena anak tidak diberi kesempatan memilih kegiatan yang menarik bagi mereka. Hal ini juga bertentangan dengan teori Erikson. Menurut Erikson (1963) pada usia pra sekolah kira-kira 3-5 tahun adalah masa insiatif dengan rasa bersalah (initiative versus guilt). Implikasi teori ini guru harus mengupayakan agar anak didik secara demokratis dan mengupayakan memberikan kondisi yang kondusif dan menantang.

Terbatasnya waktu yang dialokasikan untuk pembelajaran dukungan ekologi di TK AR Rahman selama ini yaitu hanya satu jam telah membuat guru kesulitan merancang pembelajaran dengan menggunakan metode. Hal ini berakibat pada kurangnya kesempatan bagi peserta didik untuk aktif bersosialisasi.

3. Pembahasan Pengembangan Model Konseptual 
Pembelajaran dukungan ekologis berbasis perkembangan sosial merupakan pembelajaran yang mengutamakan keterampilan proses dan konten sosial melalui dukungan esteem (emosional, informasi dan motivasi). Ada tiga karakteristik model dukungan ekologi berbasis perkembangan sosial anak yaitu: (1) Dukungan esteem (emosional, informasi, alat dan motivasi); (2) Efektivitas dukungan sosial; (3) Sumber-sumber dukungan ekologis perkembangan sosial.

Selain lima karakteristik, ada empat prinsip model pembelajaran dukungan ekologi berbasis perkembangan sosial, yaitu: (1) Pembelajaran berpusat pada anak; (2) Pembelajaran Terpadu; (3) Pembelajaran melalui bermain; (4) Pembelajaran dibuka dengan menggunakan metode.

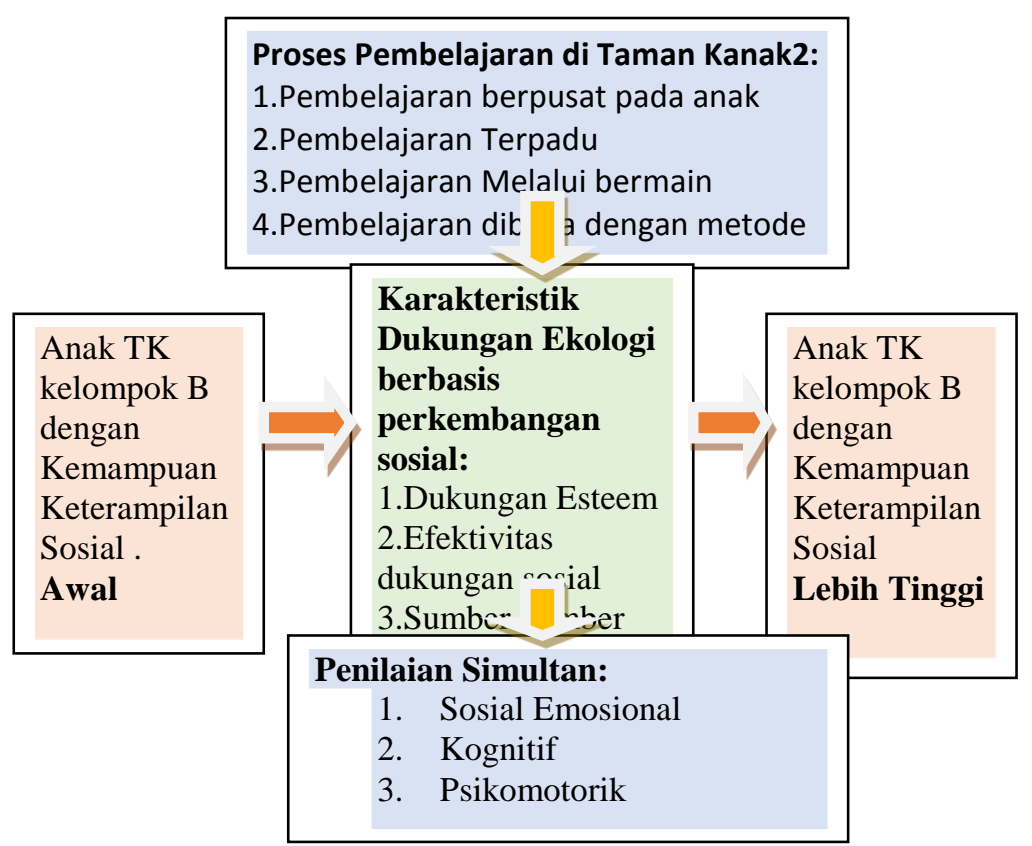

Gambar: Rancangan Model Konseptual

Pengembangan model konseptual dukungan ekologi berbasis perkembangan sosial merupakan program pembelajaran yang disintesis dari teori model pembelajaran, perkembangan sosial anak, pembelajaran TK dan pembelajaran dukungan ekologi berbasis perkembangan sosial berupa pembelajaran keterampilan proses dan konten perkembangan sosial melalui pengalaman multisensori yang mementingkan interaksi manusia dengan lingkungan sekitarnya, dengan pendekatan dan penilaian yang berpusat pada anak, menggabungkan pembelajaran proyek dan bermain dalam suatu pembelajaran terpadu dengan lima karakteristik dan lima prinsip pembelajaran.

Teori Piaget menjelaskan arah anak berfikir, memahami dan belajar karena piaget menyakini kecerdasan merupakan proses kognitif yang diperoleh anak melalui kegiatan kosentrasi. Melalui kegiatan kosentrasi, anak melakukan pengamatan terhadap objek secara langsung di lingkungannya. Menurut Buzan (2005) anak perlu belajar dengan prinsip pengulangan. Semakin baik melatih penggunaan ingatan, semakin banyak hubungan yang dibuat 
di otak dan semakin mudah kita mengingat sesuatu. Menurut Brewer, perkembangan sosial emosional akan terstimulasi melalui bermain.

\section{Simpulan dan Saran}

Dari hasil dan pembahasan dapat disimpulkan bahawa dari deskripsi umum dari data penelitian menunjukkan bahwa tingkat bersyukur orang tua anak tunagrahita termasuk ke dalam kriteria tinggi dalam mempengaruhi semangat dalam mendidik anak dan tingginya kesejahteraan subjektif orang tua anak tunagrahita. Hal ini berarti bahwa orang tua anak tunagrahita mampu bersemangat dalam mendidik anaknya dan menerima keadaan anaknya dengan lapang dada.

\section{Daftar Pustaka}

Amir Hasan Dawi. (2006). Sosiologi Pendidikan. Penteorian Sosiologi dan Pendidikan.

Bunu, H. Y. (2012). Masalah Anak Taman Kanak-Kanak Menurut Guru Dan Orang Tua Serta Implementasiya Dalam Bimbingan Dan Konseling. Jurnal Bimbingan Konseling, 1(2), 9.

Goleman, D. (2009). Ecological intelligence, Mengungkap Rahasia di balik produk-produk yang kita beli. Jakarta: Gramedia.

Hijriati, H. (2016). Tahapan perkembangan kognitif pada masa early childhood. Pasca Sarjana Pendidikan Guru Raudhatul Athfal, 1(2), 33-49.

Machmud, H. (2013). Pengaruh pola asuh dalam membentuk keterampilan sosial anak. JPUD, 6(1), 131-137.

Prasadja, H. (2008). Activities, Relationship and Role of Children, as well as Social Support for Urban Children: Exploration of Development Ecology Theory.

Spence, S. H. (2003). Social Skills Training with Children and Young People: Theory, Evidence and Practice. Child and Adolescent Mental Health, 8(2), 84-96. https://doi.org/10.1111/1475-3588.00051

Suyanto, S. (2005). Dasar-Dasar Pendidikan Anak Usia Dini. Yogyakarta: Hikayat Publishing. 
https://ejournal.radenintan.ac.id/index.php/konseli 